\title{
Insecticidal selectivity of jayanti plant (Sesbania sesban) for integrated control of diamondback moth (Plutella xylostella)
}

\author{
SURIPTO", SUKIMAN, ERIN RYANTIN GUNAWAN \\ Research Group of Plant Ecology, Program of Biology, Faculty of Mathematics and Natural Sciences, Universitas Mataram. Jl. Majapahit No.62, \\ Gomong, Selaparang, Mataram 83126, West Nusa Tenggara, Indonesia. Tel.: +62-370-641724, "email: suriptobio@unram.ac.id
}

Manuscript received: 14 June 2017. Revision accepted: 22 December 2017.

\begin{abstract}
Suripto, Sukiman, Gunawan ER. 2017. Insecticidal selectivity of jayanti plant (Sesbania sesban) for integrated control of diamondback moth (Plutella xylostella). Asian J Agric 1: 80-84. It has been known previously that leaves of the jayanti plant (Sesbania sesban (L.) Merr.) contain insecticidal ingredients. This study aimed to evaluate the insecticidal selectivity of various extract fractions of S. sesban leaf for the integrated control of cabbage pest, the diamondback moths (Plutella xylostella). Dried leaf powders from S. sesban were extracted in stages by using hexane, dichloromethane (DCM), ethanol, and water, successively. Each insecticidal performance of $S$. sesban leaf extract fractions were tested against two types of test insects, namely P. xylostella larvae as target and Diadegma semiclausum imago as non-target insects according to completely randomized design in the cabbage plantation at the village of Sembalun, East Lombok, Indonesia. Each mortality data of $P$. xylostella larvae and D. semiclausum imago was processed by probit analysis to determine the concentration of the death of $50 \%$ of test insects $\left(\mathrm{LC}_{50}\right)$ of each test extract. The results showed that the $\mathrm{LC}_{50}$ of $S$. sesban leaf extracts classified into four fractions, namely hexane, DCM, and water extract fractions to $P$. xylostella larvae successively was $343.71,294.78,29.95$, and $1197.13 \mathrm{ppm}$, and to D. semiclausum imago row was $305.5,121.56,37.38$, and 1043.70 $\mathrm{ppm}$. The results showed that the insecticidal activity of $S$. sesban leaf ethanol extract fraction was selective because its selectivity value is 1.25 . On the other hand, each insecticidal performance of three $S$. sesban leaf extracts, i.e., hexane, DCM, and water extract fractions, respectively is not selective, with the selectivity values are $0.89,0.41$, and 0.87 .
\end{abstract}

Keywords: Diadegma semiclausum, insecticidal selectivity, Plutella xylostella, Sesbania sesban

\section{INTRODUCTION}

As a producer of vitamins and minerals, vegetables are a source of nutrients required for the human body. Many vegetables, like cabbages, are consumed by humans. One of the factors causing low production of cabbage vegetables in Indonesia is due to pests. There are two important types of pests that attack cabbage plants, namely Plutella xylostella L. and Crocidolomia binotalis Zell. As a result of the attack of cabbage worms (larvae of $P$. xylostella), it is estimated that cabbage crop production could decline by more than 90\% (Verkerk and Wright 1996).

The use of insecticides to control pests that destroy cabbages, has cost more than 1 billion US $\$$ per year (Talekar and Shelton 1993) worldwide. On the other hand, the practice of pest control with insecticides of synthetic chemicals in excess can cause problems, such as the increasing resurgence and pest resistance, and the declining population of parasitoid as a natural control agent (Coasts 1994; Suripto and Sukiman 2016).

Based on fact the seriousness of the diamondback moth pest problem, it is necessary to learn the application of natural or biological insecticides to reduce the use of synthetic chemical insecticides. Leaves of the jayanti plant (Sesbania sesban (L.) Merr.) have been known to have a high content of saponins, which has anti-insect activity (Mahato and Nandy 1991; Suripto et al. 2010). However, the effectiveness of the application of $S$. sesban insecticides for controlling diamondback moth, P. xylostella in the field is not yet known.

This research was aimed to determine the insecticidal selectivity $\left(\mathrm{LC}_{50}\right)$ of various extract fractions of $S$. sesban leaf against two test types of insects, namely $P$. xylostella as the target insect and Diadegma semiclausum as the nontarget insect.

\section{MATERIALS AND METHODS}

\section{Extraction of the active insect repellent compounds from Sesbania sesban Leaf}

Leaves of a two-year old or more of Sesbania sesban (L.) Merr. species were collected. After wind drying, the leaves were milled and powdered. Later they were extracted in stages to collect the active insect repellent compounds using solvents series, which increased polarity in succession, namely hexane, dichloromethane (DCM), ethanol, and water.

Extraction was done by maceration of dry $S$. sesban leaf powders by procedure according to Harborne (1998). The solvent on each extract fraction was evaporated using a vacuum rotary evaporator and then moved into the cup resulting viscous extract condensed further in the evaporation chamber. The resulting paste form extracts were incorporated into a dark bottle before used in the bioassay. 


\section{Producing larvae of Plutella xylostella and imago of Diadegma semiclausum}

Plutella xylostella insects were collected in the cabbage plantation in The Sembalun Lawang Village, Lombok Timur Regency, Nusa Tenggara Barat Province, Indonesia.

Producing Larvae of $P$. xylostella was done by using cabbage as an attractant for $P$. xylostella to lay eggs and as feed for the larvae (instar 1 to III) with the procedures according to Solichah et al. (2004) and Suripto and Sukiman (2015) until reaching a sufficient population for bioassay.

Pupa of D. semiclausum was collected from the cabbage plantation from the same location. Mass breeding imago of D. semiclausum from their pupa was carried in a nylon cage $50 \mathrm{~cm}$ x $50 \mathrm{~cm}$ x $40 \mathrm{~cm}$ with diameter $2 \mathrm{~m}$ for each mesh. By using a solution of pure bee honey as feed in accordance with the procedures according to Wing and Keller (2008) and Suripto and Sukiman (2015) to obtain a sufficient population for bioassay.

\section{Bioassay}

Insecticidal test of extract fractions of $S$. sesban leaf against $P$. xylostella and D. semiclausum was carried out using six concentration treatments based on the Complete Randomized Design (CRD) with the procedure of AVRDC (Khaidir and Hendrival 2013; Supartha et al. 2014; Suripto and Sukiman 2016).

The treatment on P. xylostella larvae mortality test was given by spraying the extract solution in accordance with the concentration of each treatment on each test cabbage leaf surface infected by larvae of $P$. xylostella. The variables measured were the percentage of the number of dead larvae after six hours of treatment.
Imago of D. semiclausum was released in each nylon cage and fed using a solution of pure bee honey. The treatment was done by spraying a solution of the extract according to each concentration treatment into a confinement chamber containing the test cabbage crops and D. semiclausum imago (40 animals per cage). The variables measured were the percentage of the number of $D$. semiclausum imago died after six hours of treatment. The work flowchart of the insecticidal selectivity evaluation of various $S$. sesban leaf extract fractions against $P$. xylostella larvae and D. semiclausum imago can be seen in Figure 1.

\section{Data analysis}

Each mortality data of $P$. xylostella larvae and $D$. semiclausum imago was processed by probit analysis (Busvine 1974) to produce the $\mathrm{LC}_{50}$ (the concentration of the death of $50 \%$ of test insects) of each test extract.

Based on the $\mathrm{LC}_{50}$ on P. xylostella and D. semiclausum, the value of insecticidal selectivity (IS) can then be determined by using the formula according to Wang et al. (2004) as follows:

\section{LC $_{50}$ on P. Xylostella, as target insect type}

$$
\mathrm{IS}=\longdiv { \mathrm { LC } _ { 5 0 } \text { on } D \text { . semiclausum, as non-target insect } }
$$

Criteria used to determine the selectivity (IS) were as follow: (i) If IS > 1, then insecticidal selectivity of the test extract fraction is high or selective; (ii) If IS $\leq 1$, then insecticidal selectivity of the test extract fraction is low or not selective.

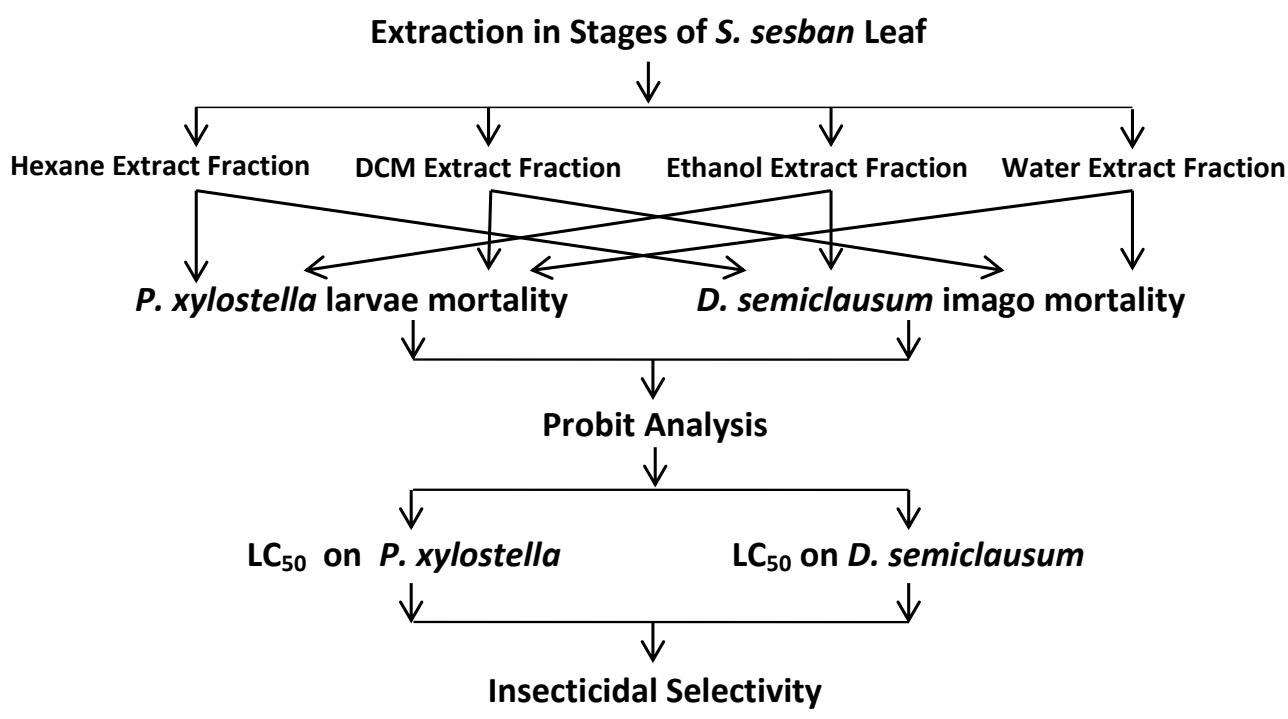

Figure 1. The flowchart of evaluating insecticidal selectivity of various $S$. sesban leaf extract fractions 


\section{RESULTS AND DISCUSSION}

Four extract fractions of $S$. sesban leaf, namely extract fraction-hexane,-DCM, -ethanol, and- water were respectively lethal acute toxic against the diamondback moth (larvae of $P$. xylostella) and the parasitoid, imago of wasp beetle (D. semiclausum). However, toxicity of the extract fraction-ethanol of $S$. sesban leaf against larvae of $P$. xylostela was much higher than the toxicity of the other three extract factions. Mortalities of $P$. xylostella larvae and imago of $D$. semiclausum in each $S$. sesban leaf extract fraction treatment can be seen in Figure 2.

Four extract fractions of $S$. sesban leaf, namely extract fraction-hexane,-DCM, -ethanol, and-water were respectively causing lethal acute toxicity against the diamondback moth (larvae of $P$. xylostella) and the parasitoid, imago of wasp beetle (D. semiclausum). However, toxicity of the extract fraction-ethanol of $S$. sesban leaf against larvae of $P$. xylostela, was much higher than the toxicity of the other three extract factions. Mortalities of $P$. xylostella larvae and imago of $D$. semiclausum in each $S$. sesban leaf extract fraction treatment can be seen in Figure 2.

Results also showed that toxicity of the extract fractionhexane,-DCM, and -water, respectively against $D$. semiclausum, as non-target insect higher than to against $P$. xyloxtella, as target insect. Thus, each of three extract fractions is considered to have properties that are not a selective insecticide for control of diamondback moth.

Unlike the other three extract factions, the extract fraction-ethanol of $S$. sesban leaf showed lower acute lethal toxicity to D. semiclausum imago compared to $P$. xylostella larvae. Thus, the extract fraction-ethanol of $S$. sesban leaf can be considered to have insect repellent properties which are selective for controlling diamondback moth, because it is very toxic to $P$. xylostella larvae as a target insect and it's toxicity is very low or not toxic to the parasitoid, $D$. semiclausum imago as non-target insects. Comparison of $\mathrm{LC}_{50}$ (Concentrations of death of $50 \%$ of test animals) of four extract factions of $S$. sesban leaf against $P$. xylostella larvae and $D$. semiclausum imago and insecticidal selectivity values, results of probit analysis can be seen in Table 1.

Table 1. $\mathrm{LC}_{50}$ (in ppm) of various extract fractions of Sesbania sesban leaf against Plutella xylostella larvae as target insects and Diadegma semiclausum imago as non-target insects

\begin{tabular}{llll}
\hline $\begin{array}{l}\text { Extract } \\
\text { Fraction }\end{array}$ & $\boldsymbol{P}$. xylostella & $\begin{array}{l}\text { D. } \\
\text { semiclausum }\end{array}$ & Selectivity \\
\hline hexane & 343.7101 & 305.5448251 & 0.888961 \\
DCM & 294.7871 & 121.5585483 & 0.41236 \\
ethanol & 29.94509 & 37.37949173 & $\mathbf{1 . 2 4 8 2 6 8}$ \\
water & 1197.129 & 1043.699945 & 0.871836 \\
\hline
\end{tabular}

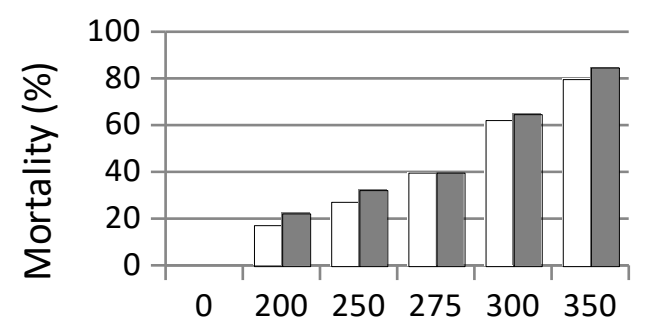

Concentrat in (ppm)

A

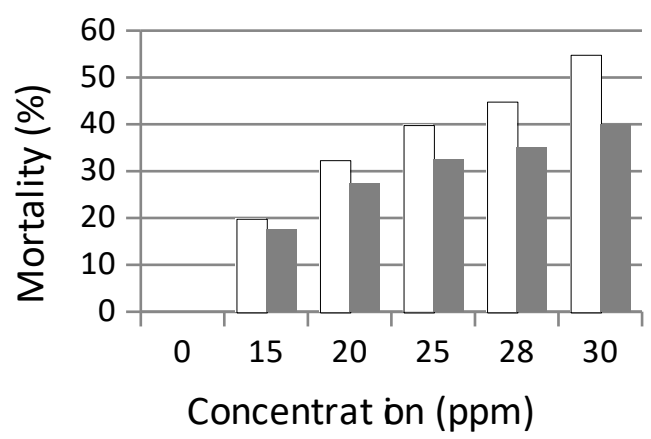

C

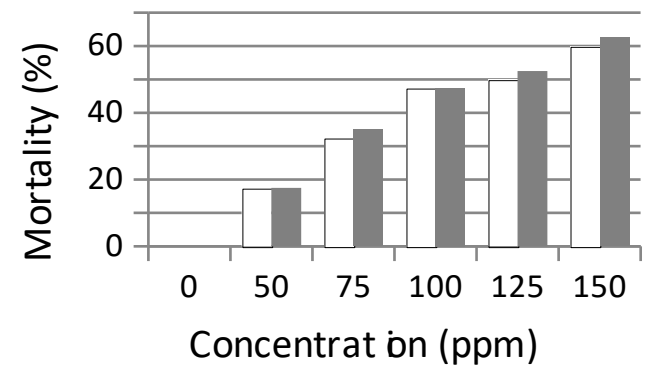

B

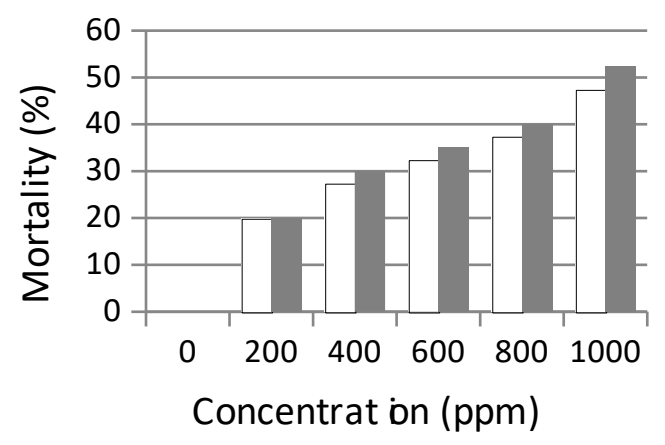

D

Figure 2. Mortality of Plutella xylostella larvae ( $\square$ ) dan Diadegma semiclausum imago $(\square$ ) in various S. sesban leaf extract fraction tretments: (a) extract fraction-hexane, (b) extract fraction-DCM, (c) extract fraction-ethanol, dan (d) extract fraction-water 
Table 2. Acute lethal toxicity of Sesbania sesban leaf extracts to larvae of Plutella xylostella and imago of Diadegma semiclausum and their selectivity (Suripto et al. 2010)

\begin{tabular}{|c|c|c|c|}
\hline \multirow[b]{2}{*}{$\begin{array}{l}\text { Solvent for } \\
\text { extraction }\end{array}$} & \multicolumn{2}{|c|}{ LC $_{50} 24$ hours (ppm) } & \multirow[b]{2}{*}{$\begin{array}{l}\text { The value of } \\
\text { selectivity (S) }\end{array}$} \\
\hline & $\begin{array}{c}P . \\
\text { xylostella }\end{array}$ & $\begin{array}{c}\text { D. } \\
\text { semiclausum }\end{array}$ & \\
\hline Hexane & 343,71 & 305,54 & 0,8890 \\
\hline DCM & 134,77 & 121,56 & 0,9020 \\
\hline Ethanol & 29,62 & 37,39 & 1,2619 \\
\hline Water & 5071,55 & 2689,61 & 0,5303 \\
\hline
\end{tabular}

Each $S$. sesban leaf extract, obtained by using a single solvent such as hexane and DCM are shown to have lower selectivity for the control of caterpillar cabbage, using $P$. xylostella larvae as target animal and imago $D$. semiclausum as non-target animal, compared with ethanol extract (Table 2) (Suripto et al. 2010).

It is known that the active component of anti-insects from $S$. sesban leaf is a class of saponins (Suripto et al. 2010). The active ingredient in the form of group saponins from $S$. sesban leaf extract can affect the permeability of cell membranes, including nerve cells in the larvae of $P$. xylostella treated with the extract. According to Francis et al. (2002), changes in the nerve cell membrane permeability can interfere with the transmission of nerve cells, and one consequence is the removal of acetylcholine too fast. This incredible accumulation of acetylcholine causes muscle spasms quickly followed by swelling, paralysis and subsequent death of the larvae of $P$. xylostella.

Because of the insecticidal ingredient of the $S$. sesban leaf, in this case extract, fraction-ethanol has a very high lethal acute toxicity against $P$. xylostella, but not toxic or very low toxicity to the parasitoid, $D$. semiclausum. The use of natural insecticide from $S$. sesban plant can be considered quite effective and efficient for controlling diamondback moth. With the $\mathrm{LC}_{50}$ is 29.95 ppm, and when each $10 \mathrm{~mL}$ of the extract solution is sprayed enough for each plant cabbage, then for the applications to 100 thousand cabbage plants required only $29.95 \mathrm{~g}$ of the extract fraction-ethanol of $S$. sesban leaf. In this study, the mass of extract fraction-ethanol produced by $20 \%$ of the dry weight from $S$. sesban leaf powders extracted. Therefore, the mass of $29.95 \mathrm{~g}$ of the extract fraction can be obtained from the extraction of approximately $150 \mathrm{~g}$ of $S$. sesban leaf dried powders.

Saponins of S. sesban plant may not be harmful to plant cabbage. The content of bioactive form of saponins from leaves of $S$. sesban is also harmless to animals and humans because this is only lethal acute toxic when it is administered intravenously, but very low toxicities when administered orally (Francis et al. 2002; Quetin-Leclerq et al. 1992). It is possibly safe as a use of insecticide, containing an active ingredient extracted from S. sesban. This is also based on the fact that leaves of $S$. sesban were often used by farmers as green manure (Heyne 1998) and were also frequently used as a livestock feed mixer (Shqueir et al. 1989).
Altogether, S. sesban plants can be developed as a source of natural insecticide for integrated control of diamondback moth, which is feasible for farmers and secure environment. This is in accordance with the criteria for selection of plants as a source of natural insecticide according to Hamburger and Hostettmann (1991) and Schmutterer (1997), i.e., the high toxicity against target insects but very low toxicity to natural enemies or nontarget insects.

\section{Conclusion}

One of four leaf extract fractions of Jayanti plant $(S$. sesban) studied, the extract fraction-ethanol has the highest acute lethal toxicity against $P$. xylostella larvae, but its toxicity is very low to the parasitoid, D. semiclausum. Insecticidal activity of the extract fraction-ethanol of $S$. sesban leaf is considered selective for integrated control for diamondback moth. On the other hand, the other three extract fractions i.e. extract fraction-hexane, -DCM, and water have unselective insecticidal activity for controlling diamondback moth, because each of their toxicity to $P$. xylostella as a target insect was higher than to $D$. semiclausum as a non-target insect type.

\section{ACKNOWLEDGEMENTS}

The study was financially supported by Hibah Bersaing, The Directorate General of Higher Education, Ministry of Research, Technology and Higher Education, Indonesia.

\section{REFERENCES}

Busvine JR. 1974. A Critical Review of The Techniques for Testing Insecticides. Common Wealth Agricultural Bureaux, London.

Coasts JR. 1994. Risks from natural versus synthetic insecticides. Ann Rev Entomol 39: 489-515.

Francis G, Kerem Z, Makkar HPS, Becker K. 2002. The biological action of saponins in animals system: a review. Br J Nutr 88: 587-605.

Hamburger M, Hostettmann K. 1991. Bioactivity in plants: The link between phytochemistry and medicine phytochemistry. Phytochemistry 30 (12): 3864-3874.

Harborne AJ. 1998. Phytochemical Methods A Guide to Modern Techniques of Plant Analysis. Elsevier, The Nederlands.

Heyne K. 1987. Tumbuhan Berguna Indonesia. Yayasan Sarana Wana. Jakarta. [Indonesian]

Khaidir A, Hendrival M. 2013. Pengujian penghambatan aktivitas makan dari ekstrak daun Lantara camara L. (Verbenaceae) terhadap larva Plutella xylostella L. (Lepidoptera: Yponomeutidae) J. Floratek. 8: 35-44. [Indonesian]

Mahato SB, Nandy AK. 1991. Triterpenoid saponins discovered between 1987 and 1989. Phytochemistry 30 (5): 1357-1390.

Quetin-Leclerq J, Elias R, Balansard G. 1992. Cytotoxic activity of some triterpenoid saponins. Planta Med 58: 279-281.

Shqueir AA, Brown DL, Taylor SJ, Rivkin I, Kasing KC. 1989. Effects of solvent extractions, heat treatments and added cholesterol on Sesbania sesban toxicity in growing chicks. Anim Feed Sci Technol. 27: 127-135.

Solichah C, Witjaksono A, Martono E. 2004. Ketertarikan Plutella xylostella L. terhadap beberapa macam ekstrak daun Cruciferae. Agrosains 6 (2): 80-84. [Indonesian]

Supartha NPY, Susila IW, Yuliadi KA. 2014. Keragaman dan kepadatan parasitoid yang berasosiasi dengan Plutella xylostella L. (Lepidoptera: Plutellidae) pada tanaman kubis tanpa aplikasi dan 
aplikasi insektisida. Agroekoteknologi Tropika 3 (1): 12-21. [Indonesian]

Suripto, Setiadi D, Purwoko AA. 2005. Pengaruh toksik letal dari berbagai fraksi ekstrak daun jayanti terhadap ulat kubis (Plutella xylostella). Lembaga Penelitian, Universitas Mataram, Mataram. [Indonesian]

Suripto, Gunawan ER, Tresnani G. 2010. Kinerja anti serangga dar tanaman jayanti \{Sesbania sesban (L.) Merr.\}. J. Biologi Tropis. 11 (1): 14-18. [Indonesian]

Suripto, Sukiman. 2015) Selektivitas Fisiologi Anti Serangga dari Tanaman Jayanti untuk Pengendalian Ulat Kubis (Plutella xylostella). LPPM, Universitas Mataram, Mataram. [Indonesian]

Suripto, Sukiman. 2016. Selektivitas Ekologi Anti Serangga dari tanaman jayanti untuk pengendalian ulat kubis (Plutella xylostella). LPPM, Universitas Mataram, Mataram. [Indonesian]

Talekar NS, Shelton M. 1993. Biology, ecology and management of the diamondback moth. Ann Rev Entomol 38: 275-301.
Talekar NS, Yang JC, Lee S T. 2008. Introduction of Diadegma semiclausum to control diamondback moth in Taiwan. In: Talekar NS (ed.). Diamondback Moth and Other Crucifer Pests: Proceedings of the Second International Workshop. Asian Vegetable Research and Development Center, Shanhua, Taiwan

Verkerk RHJ, Wright DJ. 1996. Multitrophic interactions and management of the diamondback moth: A review. Bull Entomol Res 86: $205-216$

Wang X, Duff J, Keller A, Zalucki MP, Liu S, Bailey P. 2004. Role of Diadegma semiclausum (Hymenoptera: Ichneumonidae) in controlling Plutella xylostella (Lepidoptera: Plutellidae): Code exclusion experiments and direct observation. Biocontrol Sci Technol 14: 571-586.

Wang XG, Keller MA. 2003. Patch time allocation by the parasitoid Diadegma semiclausum (Hymenoptera: Ichneumonidae). I. Effect of interpatch distance. J Insect Behav 16: 279-293. 